\title{
Temporal and spatial variation in reproductive investment of Atlantic cod Gadus morhua in the northern North Sea and Scottish west coast
}

\author{
Michio Yoneda ${ }^{1,2, *}$, Peter J. Wright ${ }^{1}$ \\ ${ }^{1}$ Fisheries Research Services Marine Laboratory, PO Box 101 Victoria Road, Aberdeen AB11 9DB, UK \\ ${ }^{2}$ Present address: Tohoku National Fisheries Research Institute, Shinhama, Shiogama, Miyagi 985-0001, Japan
}

\begin{abstract}
The recent decline in many fish stocks has been accompanied by marked changes in age at maturity. However, there is little information on whether other components of reproductive investment have changed and the relative roles of phenotypic plasticity or genetic selection in such change. This study explored how reproductive investment in cod Gadus morhua from different regions around Scotland has changed between a period of high $(1969,1970)$ and low $(2002,2003)$ spawning-stock size. Maturity ogives indicated that inshore North Sea cod now mature at a smaller size and younger age than they did around 1970. The relationship between potential fecundity and size indicated that cod in the inshore region are now more fecund than $30 \mathrm{yr}$ ago. Cod from the inshore region of the North Sea now have a higher fecundity at a given size and age than cod from the offshore region and the west of Scotland. There was no such spatial trend around 1970. Similarly, whilst the relative fecundity of cod in recent times is positively correlated with age, no such relationship was evident in 1969 and 1970. Nutritional influences on maturity and fecundity, particularly liver condition, were also evident from the recent study. However, the temporal and spatial differences in fecundity-size relationships were not consistent with a change in growth conditions, as there has been a significant decrease in body condition in recent times. Our findings regarding the temporal change in reproductive investment in the inshore North Sea region appear consistent with genotypic changes in life-history traits predicted to arise from intense periods of size-selective mortality.
\end{abstract}

KEY WORDS: Cod $\cdot$ North Sea $\cdot$ Maturity $\cdot$ Fecundity $\cdot$ Nutritional status $\cdot$ Population dynamics · Life-history traits

\section{INTRODUCTION}

Long-term shifts in the life-history traits of fishes, particularly size and age at maturity, have been widely reported (Law 2000, Trippel \& Mork 2004) and may be attributable to both environmental and genetic changes. Genetic change may arise from selection for early maturing genotypes in response to non-random, size-selective harvesting (Bagenal 1973, Rijnsdorp 1994, Trippel 1995, Trippel et al. 1997, Law 2000). Environmental factors such as temperature and food availability affect somatic growth, which in turn has consequences for the timing of maturity decisions and energy allocation to fecundity (Wootton 1990, Rijnsdorp 1994). Food availability may increase through reduced competition with conspecifics. Therefore, size-selective harvesting may have a compensatory effect on growth and age at maturation within a stock by reducing any density-dependent limitation on prey availability (Jørgensen 1990, Rijnsdorp 1994, Trippel 1995).

Whether change is genetically or environmentally induced is often difficult to determine in a natural population because any genetic response could easily be 
masked by the plasticity of phenotypic responses to varying environmental conditions (Rochet et al. 2000, Trippel \& Mork 2004). The consequences of changes in growth and survival of juveniles and adults to reproductive investment have been considered within lifehistory models (Stearns 1992). Increased mortality in the older age classes should select for a lower age at first reproduction and increased reproductive effort at all ages before the afflicted age class (Law 1979, Michod 1979). Furthermore, because fecundity is so tightly coupled to body size in fishes, a precocious but small individual would have to invest more heavily in egg production with age if it is to compensate for its initial low fecundity (Rochet et al. 2000). This trade-off between current and future reproduction predicts that the lower fecundity at maturity, the greater it will be at later reproductive events (Rochet 1998). Experimental evidence supports such a link between reduced adult survival and selection for earlier maturation and increased reproductive effort (Reznick et al. 1990).

From the viewpoint of stock-forecasting, phenotypic variation in reproductive investment can complicate medium-term projections and hence have consequences for stock-recovery plans. This is because the current assumption that spawning-stock biomass (SSB) can be applied as a proxy for stock reproductive potential in stock-recruitment relationships may be invalid if fecundity per SSB is highly variable (Trippel et al. 1997, Marshall et al. 1998, Scott et al. 1999). In addition, genetically induced changes in reproductive traits have the potential to lead to a low yield stock and thus have major repercussions to any long-term recovery plans (Law 2000).

The Atlantic cod Gadus morhua is one of the most highly exploited species in the world, and several stocks are now close to collapse (Myers et al. 1996, Cook et al. 1997, Hutchings 2000). Over the last century the landings of North Sea cod increased rapidly between the mid-1960s and mid-1980s in response to several strong year-classes, as in other gadoid species (Cushing 1984). They subsequently declined rapidly, and have remained historically low over the last decade (Hislop 1996, ICES 2002a). In the North Sea and off the west coast of Scotland, the current SSB estimates of cod (2002) lie between 13.6 and $21.5 \%$ of that in 1970 (ICES 2002a). This is mainly because the fishing mortality of cod has increased since 1970 (Cook et al. 1997). As a result, there has also been a marked truncation in the upper size and age structure of the SSB in recent years (ICES 2002b). Previous studies on North Sea cod have demonstrated that there have been declines in age at maturity over the last century (Graham 1923, West 1970, Shopka 1971, Oosthuizen \& Daan 1974, Rijnsdorp et al. 1991, Rowell 1993, Cook et al. 1999). Further, Rijnsdorp et al.
(1991) demonstrated that relative fecundity (developing oocytes $\mathrm{g}^{-1}$ body weight) in southern North Sea cod increased during the 1970s and 1980s. However, the relation of such changes in lifetime energy allocation to reproduction has received little attention, despite its significance to understanding possible fishing effects (Rochet et al. 2000). Given the precarious state of the North Sea and Scottish west coast cod stocks, there is now an urgent need for current biological information (ICES 2002a). Further, as recent genetic analysis suggests the presence of geographically distinct spawning populations of cod within the North Sea (Hutchinson et al. 2001), it is necessary to consider regional variation in life-history traits. Atlantic cod do show distinct growth and reproductive characteristics between and even within stocks (Brander 1994). Clearly, any analysis of temporal changes in reproductive investment cannot be considered without considering spatial differences.

The purpose of this study was to compare relationships between age, size, maturity, nutritional status and fecundity for cod in Scottish waters in 2002 and 2003 with those reported for the same regions in 1969 and 1970 (West 1970). We first examined possible regional differences in reproductive investment in relation to recent evidence on population structuring (Hutchinson et al. 2001). Next, we investigated whether there have been significant changes in reproductive investment between the 2 periods. Finally, the possible causes of these trends are discussed with respect to predictions about environmentally and genetically induced changes in life-history traits.

\section{MATERIALS AND METHODS}

Specimens of Gadus morhua were obtained from research vessels and commercial sources between January and March in 2002 and 2003. Additional specimens for fecundity estimate were collected in 1999. Arrangements to provide commercial samples were made with fishing vessels operating in the northern North Sea and off the west coast of Scotland (Fig. 1). In the North Sea specimens were collected from 4 locations: Shetland Isles, Moray Firth, Viking Bank and central North Sea. West coast specimens were caught mainly at 3 locations: Butt of Lewis, North Minch and South Minch. In accordance with the population structuring identified by Hutchinson et al. (2001), the sampling locations in the North Sea were classified into an inshore and offshore area depending on whether they fell east or west of $0^{\circ}$. All specimens from the commercial vessels were kept on ice between capture and measurement. The total length of all specimens was measured to the nearest $1 \mathrm{~cm}$. Body weight and gutted 


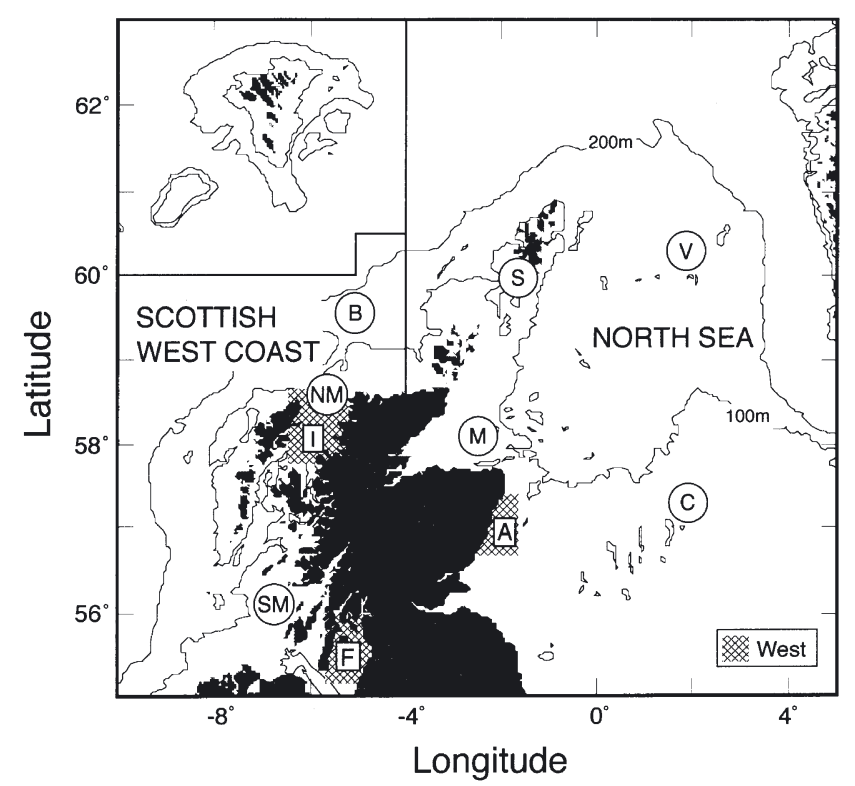

Fig. 1. Collection areas of Gadus morhua collected in waters off Scotland in 1969 and 1970 (West 1970) and in 2002 and 2003. A: Aberdeen Bay; B: Butt of Lewis; C: Central North Sea; F: Firth of Clyde; I: Inner Hebrides; M: Moray Firth; NM: North Minch; S: Shetland Isles; SM: South Minch; V: Viking Bank

body weight (GW) were determined to the nearest $1 \mathrm{~g}$, while ovarian weight (OW) and liver weight (LW) were measured to the nearest $0.1 \mathrm{~g}$. Otoliths were collected for identification of individual age. Oocyte size distribution in the ovary of cod is homogenous during vitellogenesis (Kjesbu et al. 1991, Thorsen \& Kjesbu 2001), therefore the middle portions of the ovarian lobe were excised and fixed in $8 \%$ neutral-buffered formalin for histological observation and fecundity estimate. Following fixation, ovarian portions were dehydrated and embedded in Methacrylate polymer resin (Historesin, LKB). Methacrylate polymer resin sections $3 \mu \mathrm{m}$ thick were stained with a $0.5 \%$ solution of toluidine blue.

The data on length, age, GW, maturation and fecundity from West (1970) were used to compare with recent collections of cod from inshore areas of the North Sea and off the west coast of Scotland. Specimens were obtained from commercial vessels in Aberdeen Bay (inshore North Sea) and the Inner Hebrides (west coast) during the spawning season between December and May in 1969 and 1970 (Fig. 1). Data on maturity were also available from the Firth of Clyde (west coast). Each specimen was measured and weighed, and then the ovary was removed and weighed. The otoliths were taken for ageing. The macroscopic classification of maturity stages of the ovaries made by West (1970) was equivalent to that of
Poulsen (1931) with a few modifications. Most specimens were examined within $24 \mathrm{~h}$ of capture.

The relative liver index $(H)$ and relative condition factor $\left(K_{;}\right.$Le Cren 1951) were used in the analysis of the effect of body condition on maturity and fecundity in recently collected cod. $H$ and $K$ were calculated as:

$$
\begin{aligned}
& H=\left[\frac{\mathrm{LW}}{\text { predicted LW }}\right] \\
& K=\left[\frac{\mathrm{GW}}{\text { predicted } \mathrm{GW}}\right]
\end{aligned}
$$

where LW = liver weight $(\mathrm{g})$ and GW = gutted body weight (g). Predicted LW and GW were based on data obtained from commercial, discard and research vessels in the northern North Sea and off the west coast of Scotland throughout most of the year in 1999, 2002 and 2003. This data set was used to determine inter-annual and seasonal variations in the body condition indices. These values were calculated as:

$$
\begin{gathered}
\text { predicted } \mathrm{LW}=3.70 \times 10^{-3} \times \mathrm{S}^{1.27} \\
\left(\mathrm{n}=3582, \mathrm{r}^{2}=0.860, \mathrm{p}<0.001\right) \\
\text { predicted } \mathrm{GW}=7.34 \times 10^{-3} \times \mathrm{L}^{3.06} \\
\left(\mathrm{n}=4701, \mathrm{r}^{2}=0.996, \mathrm{p}<0.001\right)
\end{gathered}
$$

where $\mathrm{S}=$ somatic weight and $\mathrm{L}=$ total length $(\mathrm{cm})$. Somatic weight was expressed as body weight minus gonad weight.

To examine the effect of body condition on potential fecundity (PF) between the different periods, the relative condition factor $(K n)$ was calculated as:

$$
K n=\left[\frac{\mathrm{GW}}{\text { expected GW }}\right]
$$

where GW = gutted body weight $(\mathrm{g})$ and

$$
\begin{gathered}
\text { expected GW }=6.79 \times 10^{-3} \times \mathrm{L}^{3.08} \\
\left(\mathrm{n}=326, \mathrm{r}^{2}=0.976, \mathrm{p}<0.001\right)
\end{gathered}
$$

where $\mathrm{L}=$ total length $(\mathrm{cm})$. Expected GW was based only on the data for analysis collected during the 2 periods.

Maturity. Estimates of length and age at sexual maturity in 2002 and 2003 were based on the examination of females collected between January and March of those years. Sexually mature individuals were defined as those with maturing, spawning and spent stages of ovaries based on macroscopic (ICES 1999) and histological observations. Histologically, in the maturing stage of ovary the most advanced oocytes are in the early to late vitellogenesis stage, and in the spawning stage they have reached the migratory to mature (hydrated) stage. At the spent stage, ovaries contain postovulatory follicles and/or some degenerat- 
ing vitellogenic oocytes. A total of 1517 specimens (13 to $111 \mathrm{~cm}$ in length) were used to estimate size at maturity, a total of 606 (Ages 1 to $8 \mathrm{yr}$ ) to estimate age at maturity. In addition, the effect of body condition $(H$ and $K$ ) together with length at maturity was examined for cod in collected in 2002 and 2003.

Estimates of length and age at maturity in 1969 and 1970 were based on 590 specimens $(31$ to $101 \mathrm{~cm}$ in length, Ages 2 to 8 yr) taken from West (1970). Macroscopic staging followed a classification similar to that applied in 2002 and 2003 (ICES 1999).

Fecundity. Fecundity was estimated for specimens with ovaries containing oocytes in the late vitellogenesis stage $(>520 \mu \mathrm{m})$ using the auto-diametric method (Thorsen \& Kjesbu 2001). This oocyte size is considered reasonable for estimation of potential fecundity in cod using this method. Potential fecundity is defined as the number of vitellogenic oocytes in the ovary just prior to spawning (Kjesbu et al. 1998). After 150 to 350 particles had been measured using NIH (National Institute of Health, US) image-analysis, the mean oocyte diameter (OD, $\mu \mathrm{m}$ ) of each fresh ovary was estimated as:

$$
\begin{gathered}
\mathrm{OD}=-0.82+(1.02 \times \text { ODF }) \\
\left(\mathrm{n}=24, \mathrm{r}^{2}=0.985, \mathrm{p}<0.001,355 \leq \mathrm{ODF} \leq 750\right)
\end{gathered}
$$

where ODF = mean oocyte diameter in the formalinfixed ovary $(\mu \mathrm{m})$. The ODF of an individual ovary was based on 50 to 150 particles preserved in $8 \%$ formalin for 3 to 6 mo. In general the size of formalin-fixed samples varies according to the duration of preservation (Hunter 1985). In this study fecundity samples in 2002 and 2003 were examined within 5 mo of collection, whilst the 1999 specimens were used 3 yr after collection. However, there was no significant year effect on the oocyte density-ODF regression (generalized linear model [gamma family, log-link], $\mathrm{n}=69, \mathrm{R}^{2}=0.957$; $<$ 0.001 for ODF; $\mathrm{p}=0.283$ for year).

The predicted potential fecundity $\left(\mathrm{PF}_{\mathrm{p}}\right)$ was expressed by the following regressions (Thorsen \& Kjesbu 2001):

$$
\begin{gathered}
\mathrm{PF}_{\mathrm{p}}=\mathrm{OW} \times 2.139 \times 10^{11} \times \mathrm{OD}^{-2.700} \\
(300 \leq \mathrm{OD} \leq 850)
\end{gathered}
$$

where OW = ovarian weight $(\mathrm{g})$, and $\mathrm{OD}=$ mean oocyte diameter $(\mu \mathrm{m})$ of the fresh ovary.

Corrected potential fecundity $(\mathrm{PF})$ was recalculated using following equation:

$$
\mathrm{PF}=\mathrm{PF}_{\mathrm{p}} \times(100-\mathrm{AO})
$$

where $\mathrm{PF}_{\mathrm{p}}$ predicts potential fecundity from Eq. (8), and $\mathrm{AO}$ predicts percentage of atretic oocytes in the ovary (see below).

Relative fecundity is defined as the number of vitellogenic oocytes $\mathrm{g}^{-1}$ body weight (Kjesbu et al. 1998). To remove the effect of different GW among periods and areas, relative fecundity (RF) was calculated as followed:

$$
\mathrm{RF}=\left[\frac{\mathrm{PF}}{\text { expected } \mathrm{GW}}\right]
$$

where PF = potential fecundity from Eq. (9). Expected GW was calculated from Eq. (6).

Data on PF from West (1970) were used to compare with the fecundity of cod collected recently from inshore waters of the North Sea and the west coast of Scotland. Estimates of fecundity were made for specimens with 'ripening' ovaries. The ovaries were preserved in Gilson's fluid for at least 4 wk. The PF was estimated by counting vitellogenic oocytes using the volumetric method.

To account for the effects of pre-ovulatory atresia on fecundity, the percentage of atretic vitellogenic oocytes in relation to the total number of normal and atretic vitellogenic oocytes was calculated (Hunter \& Macewicz 1985, Witthames \& Greer Walker 1995). Each ovary was examined for atretic oocytes according to the criteria of Hunter \& Macewicz (1985) and Óskarsson et al. (2002). Only $\alpha$-stage atretic oocytes were counted for estimation of intensity of atresia in the ovary (Hunter \& Macewicz 1985, Witthames \& Greer Walker 1995). Histologically, $\alpha$-stage atretic oocytes were recognised as those with a disintegrated nucleus, yolk globules, and hypertrophy of the follicular cell layers. Under the binocular microscope, $\alpha$-stage atretic oocytes tended to be irregular in shape, relatively smaller than normal oocytes and of uneven transparency (Óskarsson et al. 2002). About 250 oocytes of each ovary containing atretic oocytes were counted to estimate the percentage of atretic oocytes.

Statistical analysis. A Kruskal-Wallis test followed by Dunn's multiple-comparison test or the Mann-Whitney $U$-test ( $U$-test) was used to compare each natural logarithmic transformed length and RF at age, ovarian density and body condition indices between or among groups. For the analysis of length at age, only data for Ages 1 to 4 yr were used, since all specimens at Age $\geq 5$ yr were mature.

A binomial generalized linear model (GLM) with logit-link was used to compare the length and age at maturity among areas and years and to examine the influence of length and condition measures on maturity. In the GLM, maturity was a 2-level factor representing stage of maturity (immature or mature), area was a factorial variable representing the areas (inshore North Sea, west coast of Scotland, offshore North Sea), and period was a 2-level factor representing year of capture (1969, 1970 or 2002, 2003). An additional measure of model fit was based on a pseudo-coefficient of 
determination $\left(\mathrm{R}^{2}\right)$, which was the fraction of the total variation explained by the model

$$
\mathrm{R}^{2}=\left[\frac{\text { residual deviance }}{\text { null deviance }}\right]
$$

where deviance was analogous to the residual sum of squares (Swartzman et al. 1995).

Fecundity and condition relationships between areas and periods within the overlapping size ranges were compared using GLM, incorporating a gammaresponse distribution coupled with a log-link function to connect the mean to the linear predictors. In GLMs, the mean is modelled as a function of the covariates. The GLM by fitting a model with a gamma-family distribution accounts for the increased predictor variance with increasing response variable. A log link $\left(Y=\mathrm{e}^{a x+b}\right)$ was used for weight or fecundity-body size or age relationships. The GLM (gamma family, log-link) was also used to compare the effect of condition on PF between capture periods. Condition indices were incorporated into multiple regression models, with length as the first predictor in order to examine whether nutritional state could explain variation around the PF-length relationship. Statistical analyses (analysis of deviance) were performed using S-PLUS 2000 ${ }^{\circledR}$ (MathSoft 2000).

\section{RESULTS}

\section{Spatial patterns in 1969 and 1970}

No data on length at either Age 1 or 2 yr were available in 1969 and 1970. The sizes of mature and immature cod overlapped, but within the Age 3 or 4 yr group the length of mature cod in the inshore waters of the North Sea and west coast of Scotland was significantly greater than that of immature cod (Table $1 ; \mathrm{p}<0.05)$. There was a significant difference in the length of mature fish at Age 3 yr between areas, whilst no significant difference in length of mature fish at Age 4 yr was found.

There was no significant difference in the gutted body weight (GW)-length regression between inshore North Sea and west coast areas for the overlapping size range 40 to $80 \mathrm{~cm}$ (Table $2 ; \mathrm{n}=109, \mathrm{R}^{2}=0.909 ; \mathrm{p}<$ 0.001 for length; $\mathrm{p}=0.371$ for area)

Table 1. Gadus morhua. Mean $( \pm \mathrm{SE})$ total length $(\mathrm{cm})$ at age of immature $(\mathrm{Im})$ and mature $(\mathrm{M})$ cod in different waters areas of North Sea in 1969 and 1970 and 2002 and 2003. Values with different superscripts are significantly different between/among areas $\left({ }^{\mathrm{a}, \mathrm{b}, \mathrm{c}}\right)$ or between periods $\left({ }^{*}\right)$ (Mann-Whitney $U$-test or Dunn's multiple-comparison test, $\left.\mathrm{p}<0.05\right)$. INS: inshore North Sea waters; WC: waters off west coast of Scotland; ONS: offshore North Sea waters; (n): no. of fish examined

\begin{tabular}{|c|c|c|c|c|c|c|c|}
\hline \multirow{2}{*}{ Period } & \multirow{2}{*}{$\begin{array}{c}\text { Age } \\
\text { (yr) }\end{array}$} & \multicolumn{2}{|c|}{ INS } & \multicolumn{2}{|c|}{ - WC } & ONS & \multirow[b]{2}{*}{ M } \\
\hline & & $\operatorname{Im}$ & M & $\operatorname{Im}$ & $\mathrm{M}$ & $\operatorname{Im}$ & \\
\hline \multirow[t]{3}{*}{ 1969-1970 } & 2 & $43 \pm 0.8(75)$ & $50 \pm 1.8$ & & & & \\
\hline & 3 & $55 \pm 0.5^{\mathrm{a}}(59)$ & $59 \pm 0.6^{a}(144)$ & $61 \pm 1.4^{\mathrm{b}}(12)$ & $64 \pm 0.8^{\mathrm{b}}(54)$ & & \\
\hline & 4 & $61 \pm 1.9(21)$ & $69 \pm 1.2(59)$ & & $73 \pm 0.8$ & & \\
\hline \multirow[t]{4}{*}{ 2002-2003 } & 1 & $26 \pm 1.8^{\mathrm{a}}(9)$ & & $19 \pm 1.3^{b}(6)$ & & & \\
\hline & 2 & $33 \pm 0.7^{a}(60)^{*}$ & $41 \pm 2.6(8)$ & $43 \pm 1.9^{b}(10)$ & $48 \pm 1.2(27)$ & $32 \pm 0.6^{\mathrm{a}}(13)$ & $34 \pm 5.0(3)$ \\
\hline & 3 & $49 \pm 1.8^{\mathrm{a}}(32)^{*}$ & $57 \pm 0.8^{\mathrm{a}}(63)^{*}$ & $58 \pm 1.0^{\mathrm{b}}(25)$ & $60 \pm 0.8^{\mathrm{ab}}(47)^{*}$ & $40 \pm 1.4^{\mathrm{c}}(36)$ & $61 \pm 1.3^{\mathrm{b}}(53)$ \\
\hline & 4 & 68 (1) & $70 \pm 0.8^{a}(81)$ & $69 \pm 1.6(4)$ & $69 \pm 0.8^{\mathrm{a}}(44)^{*}$ & $53 \pm 5.0$ & $73 \pm 1.7^{b}(29)$ \\
\hline
\end{tabular}

Table 2. Gadus morhua. Relationships between gutted body weight (GW, g), liver weight (LW, g) and total length (L, cm) of cod in 1969 and 1970 and 2002 and 2003 in different areas of the Scottish waters (weight $=a \mathrm{~L}^{b}$ ). Estimated weights at 50,70 and $90 \mathrm{~cm}$ $\mathrm{L}$ are shown. Abbreviations as in Table 1

\begin{tabular}{|lcrrrrrrrrr}
\hline $\begin{array}{l}\text { Parameter } \\
\text { Period }\end{array}$ & Area & (n) & $a$ & $b$ & $\mathrm{r}^{2}$ & $\mathrm{p}$ & Weight range $(\mathrm{g})$ & $50 \mathrm{~cm}$ & $70 \mathrm{~cm}$ & $90 \mathrm{~cm}$ \\
\hline GW-L & & & & & & & & & & \\
$1969-1970$ & INS & $(51)$ & $5.88 \times 10^{-2}$ & 2.58 & 0.897 & $<0.001$ & $936-6802$ & 1421 & 3386 & $(6476)$ \\
& WC & $(69)$ & $1.08 \times 10^{-2}$ & 2.98 & 0.956 & $<0.001$ & $1212-9600$ & 1248 & 3403 & 7196 \\
$2002-2003$ & INS & $(109)$ & $8.40 \times 10^{-3}$ & 3.03 & 0.974 & $<0.001$ & $455-15160$ & 1181 & 3273 & 7009 \\
& WC & $(50)$ & $1.05 \times 10^{-2}$ & 2.98 & 0.987 & $<0.001$ & $298-9859$ & 1214 & 3308 & 6996 \\
& ONS & $(47)$ & $4.59 \times 10^{-3}$ & 3.16 & 0.996 & $<0.001$ & $145-8550$ & 1073 & 3107 & 6874 \\
LW-L & & & & & & & & & & \\
$2002-2003$ & INS & $(109)$ & $3.31 \times 10^{-6}$ & 4.21 & 0.874 & $<0.001$ & $10.9-1390.0$ & 47 & 194 & 559 \\
& WC & $(50)$ & $3.40 \times 10^{-5}$ & 3.65 & 0.832 & $<0.001$ & $23.0-845.0$ & 54 & 185 & 462 \\
& ONS & $(47)$ & $4.53 \times 10^{-6}$ & 4.15 & 0.963 & $<0.001$ & $2.7-997.0$ & 51 & 206 & 584 \\
\hline
\end{tabular}



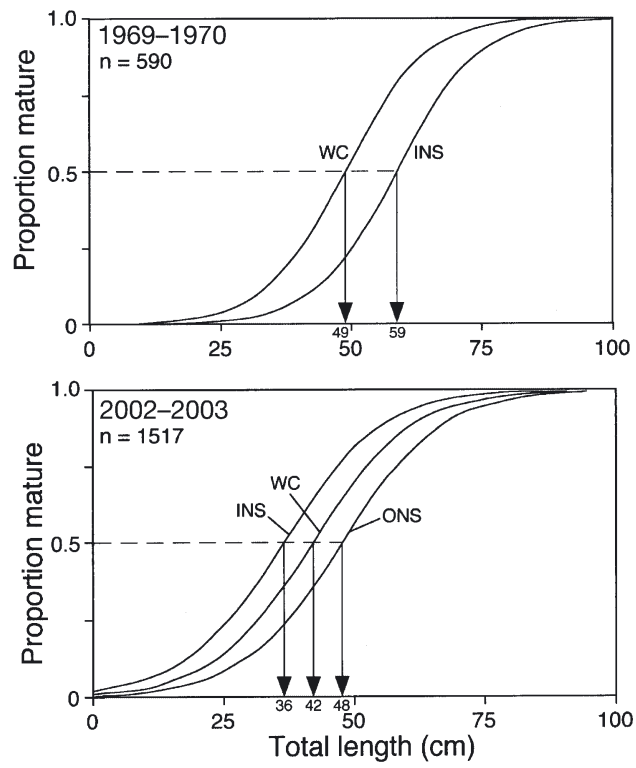

Fig. 2. Gadus morhua. Maturity ogives fitted by generalized linear model for cod from inshore North Sea (INS), off west of Scotland (WC) and offshore North Sea (ONS) in 1969 and 1970 and 2002 and 2003. Small numerals on abscissa indicate length at $50 \%$ maturity in relevant area

The initial GLM applied to data in 1969 and 1970 showed no significant year effect on maturity $(\mathrm{p}=$ 0.156), thus the data were combined in both years. Between inshore waters of the North Sea and the west coast of Scotland there were significant differences in length at maturity $\left(\mathrm{n}=590, \mathrm{R}^{2}=0.276\right.$; $\mathrm{p}<0.001$ for length $; \mathrm{p}<0.001$ for area) and age at maturity $(\mathrm{n}=590$, $\mathrm{R}^{2}=0.237, \mathrm{p}<0.001$ for age $; \mathrm{p}<0.001$ for area). Length and age at $50 \%$ maturity in cod from the North Sea and west coast were 59 and $49 \mathrm{~cm}$, and 2.9 and $2.3 \mathrm{yr}$, respectively (Fig. 2).
There were no significant year effects on the potential fecundity (PF)-length regressions within each area $(p=0.530$, North Sea; $p=0.628$, west coast). PF in inshore North Sea and west coast cod ranged from 0.328 to 5.802 and 0.659 to 6.879 million vitellogenic oocytes. There was a positive relationship between PF and length in inshore North Sea and west coast cod (Table 3). There was no significant difference in the $\mathrm{PF}$-length regression between the 2 areas within the size range 40 to $80 \mathrm{~cm}\left(n=110, R^{2}=0.596 ; p<0.001\right.$ for length $; \mathrm{p}=0.467$ for area).

The relative fecundity (RF) of inshore North Sea and west coast cod ranged from 301 to 2018 and 359 to 1261 oocytes $\mathrm{g}^{-1}$. In both areas, RF was not significantly related to age (Table 3). For Ages 3 and 4 yr there were no significant differences in RF either between ages or between areas (North Sea: $\mathrm{n}=30,661 \pm 34.4$ for Age $3 \mathrm{yr}$; $\mathrm{n}=20,660 \pm 80.9$ for Age $4 \mathrm{yr}$; $U$-test $\mathrm{p}=0.362$; west coast: $\mathrm{n}=38,695 \pm 30.9$ for Age $3 \mathrm{yr}_{;} \mathrm{n}=19,636 \pm 34.7$ for Age $4 \mathrm{yr}_{;} \mathrm{p}=0.271$; North Sea-west coast: $\mathrm{p}=0.545$ for Age $3 \mathrm{yr}_{;} \mathrm{p}=0.653$ for Age $4 \mathrm{yr}$ ).

Overall, spatial variation in the length and age at maturity in cod in 1969 and 1970 were significant whilst their fecundities in both areas were similar.

\section{Spatial patterns in 2002 and 2003}

The length of mature cod in inshore and offshore waters of the North Sea was significantly greater than that of immature cod $(U$-test, $\mathrm{p}<0.01)$ whilst in west coast cod, the length of mature and immature fish was statistically similar (Table $1 ; \mathrm{p}=0.070$ for Age $2 \mathrm{yr}_{i} \mathrm{p}=$ 0.365 for Age $3 \mathrm{yr}$ ). There were significant differences in the length of mature fish at Ages 3 and 4 yr among the 3 areas (Kruskal-Wallis test, $\mathrm{p}<0.001$ ).

Table 3. Gadus morhua. Relationship between potential fecundity $(\mathrm{PF})$ and total length $(\mathrm{L}, \mathrm{cm})\left(\mathrm{PF}=a \mathrm{~L}^{b}\right)$ and between relative fecundity (RF: PF g ${ }^{-1}$ expected gutted body wt) and age (yr) $\left(\mathrm{RF}=a\right.$ age $\left.{ }^{b}\right)$ for cod in different areas in 1969 and 1970 and 2002 and 2003. Estimated fecundities at 50,70 and $90 \mathrm{~cm} \mathrm{~L}$ or age at 3,4 and $5 \mathrm{yr}$ are shown. Abbreviations as in Table 1

\begin{tabular}{|c|c|c|c|c|c|c|c|c|c|c|}
\hline $\begin{array}{c}\text { Parameter } \\
\text { Period }\end{array}$ & Area & (n) & $a$ & $b$ & $\mathrm{r}^{2}$ & $\mathrm{p}$ & L/Age range & $\begin{array}{c}-50 \mathrm{~cm} \\
\text { Age } 3 \mathrm{yr}\end{array}$ & $\begin{array}{l}-70 \mathrm{~cm} \\
\text { Age } 4 \mathrm{yr}\end{array}$ & $\begin{array}{l}-90 \mathrm{~cm} \\
\text { Age } 5 \mathrm{yr}\end{array}$ \\
\hline \multicolumn{11}{|l|}{ PF-L } \\
\hline \multirow[t]{2}{*}{ 1969-1970 } & INS & (52) & 6.74 & 2.97 & 0.654 & $<0.001$ & $41-86$ & 0.749 & 2.035 & $(4.293)$ \\
\hline & WC & (69) & 3.89 & 3.12 & 0.744 & $<0.001$ & $48-101$ & 0.778 & 2.222 & 4.866 \\
\hline \multirow[t]{3}{*}{$2002-2003$} & INS & (109) & $3.61 \times 10^{-1}$ & 3.73 & 0.857 & $<0.001$ & $38-107$ & 0.785 & 2.752 & 7.028 \\
\hline & WC & (50) & $7.90 \times 10^{-2}$ & 4.04 & 0.871 & $<0.001$ & $41-97$ & 0.577 & 2.248 & 6.205 \\
\hline & ONS & $(47)$ & $2.70 \times 10^{-1}$ & 3.74 & 0.974 & $<0.001$ & $27-97$ & 0.610 & 2.148 & 5.498 \\
\hline \multicolumn{11}{|l|}{ RF-Age } \\
\hline \multirow[t]{2}{*}{ 1969-1970 } & INS & (52) & 561.2 & 0.097 & 0.002 & 0.752 & $3-5$ & (624) & $(642)$ & (656) \\
\hline & WC & (69) & 652.6 & 0.005 & $<0.001$ & 0.969 & $3-8$ & (656) & $(657)$ & (658) \\
\hline \multirow[t]{3}{*}{$2002-2003$} & INS & (109) & 357.8 & 0.607 & 0.199 & $<0.001$ & $2-8$ & 697 & 830 & 950 \\
\hline & WC & $(50)$ & 296.8 & 0.613 & 0.287 & $<0.001$ & $2-6$ & 582 & 694 & 796 \\
\hline & ONS & $(47)$ & 138.8 & 1.075 & 0.501 & $<0.001$ & $2-6$ & 452 & 616 & 783 \\
\hline
\end{tabular}


Table 4. Gadus morhua. Results of generalized linear model fit to data on total length $(\mathrm{L}, \mathrm{cm})$ at maturity in addition to relative liver index $(H)$ for $\operatorname{cod} \leq 80 \mathrm{~cm} \mathrm{~L}$ in different areas in 2002 and 2003. Variation explained by addition of terms and total model is based on $\mathrm{R}^{2}$ values. Proportion mature (M) was calculated as: $\mathrm{M}=1 / 1+\mathrm{e}^{-(-a+b \times \mathrm{L}+c \times H)}$. Abbreviations as in Table 1

\begin{tabular}{|cccrccc|}
\hline Area & (n) & $\begin{array}{c}\text { Source of } \\
\text { variation }\end{array}$ & Coefficients & $\mathrm{p}$ & $\mathrm{R}^{2}$ \\
\hline INS & $(455)$ & none & -10.38 & & 0.560 \\
& & L & 0.18 & $<0.001$ & 0.521 \\
& & $H$ & 1.05 & $<0.001$ & 0.039 \\
WC & $(343)$ & none & -9.60 & & 0.289 \\
& & L & 0.15 & $<0.001$ & 0.191 \\
& & $H$ & 2.63 & $<0.001$ & 0.098 \\
\hline
\end{tabular}

The calculated GW at a given length was variable among the 3 areas (Table 2). However, there was no significant difference in the GW-length regression among areas within the overlapping size-range (50 to $90 \mathrm{~cm} ; \mathrm{n}=168, \mathrm{R}^{2}=0.949 ; \mathrm{p}<0.001$ for length; $\mathrm{p}=$ 0.190 for area). There were positive relationships between liver weight (LW) and length in cod collected in 2002 and 2003 (Table 2). Among the 3 areas there was no significant difference in the LW-length regression within the size range 50 to $90 \mathrm{~cm}\left(\mathrm{n}=168, \mathrm{R}^{2}=\right.$ 0.788; $\mathrm{p}<0.001$ for length; $\mathrm{p}=0.313$ for area).

Initial GLM revealed no significant year effect on maturity between 2002 and 2003 ( $p=0.147$ ). The relationship between sexual maturity and length in cod differed significantly among the 3 areas $\left(\mathrm{n}=1517, \mathrm{R}^{2}=\right.$ $0.308 ; \mathrm{p}<0.001$ for length; $\mathrm{p}<0.001$ for area). The length at $50 \%$ maturity in inshore North Sea, west coast and offshore North Sea cod was 36, 42 and $48 \mathrm{~cm}$, respectively (Fig. 2). There was no significant difference in age at maturity among areas $\left(n=606, \mathrm{R}^{2}=\right.$ 0.274; $\mathrm{p}<0.001$ for age; $\mathrm{p}=0.737$ for area): age at $50 \%$ maturity in inshore North Sea, west coast and offshore North Sea cod was 2.7, 2.8 and 2.9 yr, respectively.

For the analysis of condition effect on maturity, only specimens of $\leq 80 \mathrm{~cm}$ in length were used, since there were significant relationships in hepatosomatic index $(H)$-length and relative condition factor $(K)$-length in specimens $>80 \mathrm{~cm}(\mathrm{p}<0.01)$. Length and $H$ had significant influences on maturity in inshore North Sea and west coast cod (Table 4). However, length explained a much higher proportion of the variation than $H$. No significant effect of $K$ on maturity was found for the 2 regions. The same model revealed that maturity of offshore North Sea cod was not influenced by $H$ or $K$ $\left(\mathrm{p}=0.483, H_{;} \mathrm{p}=0.063, K\right)$.

The initial GLM applied to the data in 2002 and 2003 showed no significant effects of year on the PF-length regressions in the inshore of the North Sea and west coast $\operatorname{cod}(p=0.112$, inshore North Sea; $p=0.309$, west coast). In offshore North Sea cod additional specimens in 1999 were also used for fecundity analysis, since the initial GLM applied to the data (3 yr) showed no significant effects of year on the PF-length regression $(\mathrm{p}=$ 0.823). Within each area there were no significant effects of sampling location on PF-length regressions ( $p=0.200$ for inshore North Sea [Shetland Isles and Moray Firth]; $p=0.172$ for west coast [Butt of Lewis, North and South Minch]; $\mathrm{p}=0.925$ for North Sea offshore [Viking Bank and Central North Sea]), so the data were combined for each location. There were positive relationships between PF and length in all areas (Table 3). Within the length range 50 to $90 \mathrm{~cm}$, there was a significant difference in the $\mathrm{PF}$-length regression among areas $\left(n=168, R^{2}=0.749 ; p<0.001\right.$ for length; $\mathrm{p}<0.001$ for area). The estimated PF of inshore North Sea cod resulted in a 17 and $36 \%$ higher estimated PF for west coast and offshore North Sea cod, respectively (Fig. 3).

Condition indices were not significantly correlated to length, with the exception of specimens $\geq 35 \mathrm{~cm}$ in the offshore region of the North Sea. PF was influenced by female condition in addition to length (Table 5). Multiple regression analysis of natural logarithmic PF in cod showed that length explained most of the variation in $\mathrm{PF}$ in all regions. However, $H$ and/or $K$ were also significant explanatory variables in all areas. In the inshore North Sea cod, all body-condition indices were significant. The effect of $H$ was significant in west coast cod, but not in offshore North Sea cod.

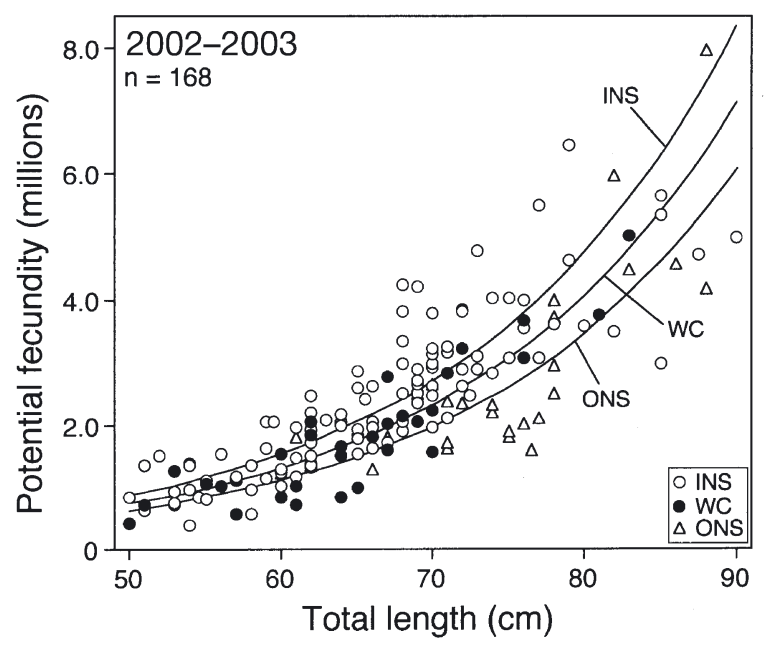

Fig. 3. Gadus morhua. Relationship between potential fecundity (millions of oocytes) and total length of cod collected from inshore North Sea (INS), off west of Scotland (WC) and from offshore North Sea (ONS) in 2002 and 2003. Regression line for generalized linear model fitted to potential fecundity at length is shown for each area 
Table 5. Gadus morhua. Effects of total length $(\mathrm{L}, \mathrm{cm})$, relative liver index $(H)$ and relative condition factor $(K)$ on potential fecundity in different waters in 2002 and 2003. All data were natural log-transformed before analysis $\left(\mathrm{PF}=a \mathrm{~L}^{b} H^{c} K^{d}\right)$. Abbreviations as in Table 1

\begin{tabular}{|c|c|c|c|c|c|c|}
\hline Area & (n) & Source of variation & Coefficients & $t$ & $\mathrm{p}$ & $r^{2}$ \\
\hline INS & (109) & $\begin{array}{l}\text { Whole model } \\
\qquad \begin{array}{c}a \\
\mathrm{~L} \\
H \\
K\end{array}\end{array}$ & $\begin{array}{l}2.46 \\
3.66 \\
0.37 \\
0.93\end{array}$ & $\begin{array}{r}1.64 \\
27.46 \\
3.92 \\
3.51\end{array}$ & $\begin{array}{r}<0.001 \\
0.104 \\
<0.001 \\
<0.001 \\
<0.001\end{array}$ & 0.890 \\
\hline WC & $(50)$ & $\begin{array}{l}\text { Whole model } \\
\qquad \begin{array}{c}a \\
\mathrm{~L} \\
H\end{array}\end{array}$ & $\begin{array}{r}23.69 \\
4.14 \\
0.60\end{array}$ & $\begin{array}{r}4.04 \\
21.83 \\
4.61\end{array}$ & $\begin{array}{l}<0.001 \\
<0.001 \\
<0.001 \\
<0.001\end{array}$ & 0.911 \\
\hline ONS & $\begin{array}{c}(36) \\
(\geq 35 \mathrm{~cm} \mathrm{~L})\end{array}$ & $\begin{array}{l}\text { Whole model } \\
\qquad \begin{array}{c}a \\
\mathrm{~L} \\
K\end{array}\end{array}$ & $\begin{array}{l}3.60 \\
3.74 \\
1.22\end{array}$ & $\begin{array}{r}1.65 \\
20.60 \\
2.16\end{array}$ & $\begin{aligned}< & 0.001 \\
& 0.113 \\
< & 0.001 \\
< & 0.05\end{aligned}$ & 0.929 \\
\hline
\end{tabular}

Sea cod at Ages 2 to 5 yr was 19 and $42 \%$ higher than for west coast and offshore cod, respectively.

A total of 69 specimens (34\%) collected from the Scottish waters had $\alpha$ stage atretic oocytes in late vitellogenic ovaries (Table 6). The highest prevalence of ovaries with $\alpha$-stage atretic oocytes was found in west coast cod (54\%). The mean relative intensity of atresia (RI) was $1.7 \%$. There was no significant difference in RI among the 3 areas (Kruskal-Wallis test, $\mathrm{p}=0.493$ ). No significant relationships between RI and length, age, $K, H$ or oocyte diameter were found $(\mathrm{p}>0.05)$. There were no significant differences in $K$ and $H$ between females with non-atretic and atretic oocytes in any one area ( $U$-test, $\left.\mathrm{p}=0.638, H_{i} \mathrm{p}=0.301, K\right)$. In females

The RF of inshore North Sea, west coast of Scotland and offshore North Sea cod ranged from 264 to 1535, 264 to 1227 and 213 to 1188 oocytes $\mathrm{g}^{-1}$, respectively. The RF was positively correlated with age in cod (Table 3 ; Fig. 4). These trends were reflected in differences in RF among age groups in the 3 areas (Kruskal-Wallis test, $p$ $<0.01$ for inshore [Ages 3, 4 and $>4$ yr groups]; $\mathrm{p}<0.01$ for west coast [Ages 2, 3 and $4 \mathrm{yr}$ ]; $\mathrm{p}<0.001$ for offshore [Ages 3, 4 and $>4 \mathrm{yr}$ ]). Within the age groups ranging from 2 to 5 yr there was a significant difference in $\mathrm{RF}$-age regression among areas $\left(\mathrm{n}=198, \mathrm{R}^{2}=0.378\right.$; $<<$ 0.001 for age $; p<0.001$ for area). The RF of inshore North

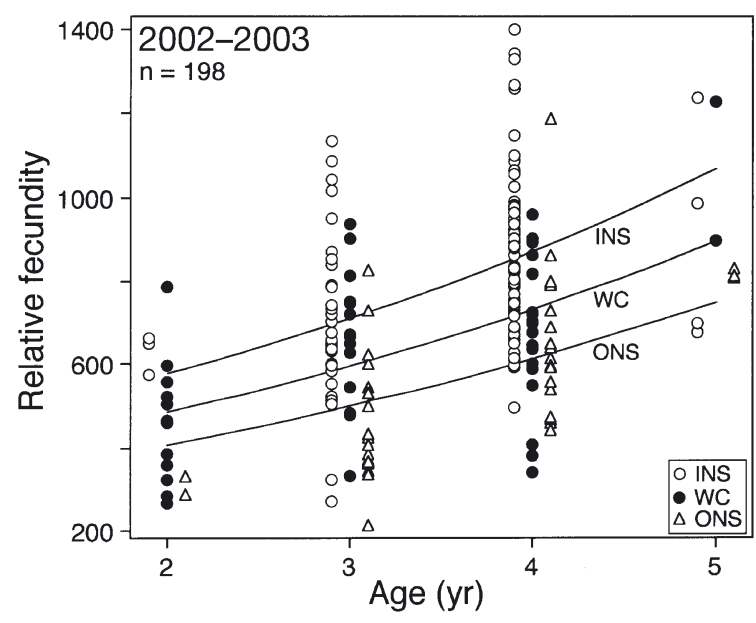

Fig. 4. Gadus morhua. Relationship between relative fecundity (number of oocytes $\mathrm{g}^{-1}$ expected gutted body wt) and total length of cod collected from inshore North Sea (INS), off west of Scotland (WC) and offshore North Sea (ONS) in 2002 and 2003. Regression line for generalized linear model fitted to relative fecundity at age is shown for each area with atretic oocytes, offshore North Sea cod had lower $K$ values than the inshore North Sea and west coast cod (Kruskal-Wallis test, $\mathrm{p}<0.001$ ), but not lower $H$ values $(p=0.171)$. There were no significant differences between predicted PF and PF in specimens in the 3 areas ( $U$-test, $\mathrm{p}=0.948$ for inshore North Sea; $\mathrm{p}=$ 0.900 for west coast; $p=0.907$ for offshore North Sea).

Overall, spatial differences in size at maturity and fecundity in cod collected in 2002 and 2003 were evident, with inshore North Sea cod maturing at a smaller size and being more fecund than west coast and offshore North Sea cod. These spatial differences were partly due to differences in body and liver condition.

\section{Temporal comparisons between 1969, 1970 and 2002, 2003}

In inshore North Sea cod, the length of immature (Ages 2 and 3 yr) and mature (Age 3 yr) cod in 2002 and 2003 was significantly smaller than in 1969 and 1970 (Table 1, $U$-test, $\mathrm{p}<0.05$ ). There was no significant difference in the length of mature fish at Age $4 \mathrm{yr}$

Table 6. Gadus morhua. Prevalence and mean $( \pm \mathrm{SE})$ relative intensity of atresia in cod with ovaries at $\alpha$-stage of atresia in different waters in 2002 and 2003. Abbreviations as in Table 1

\begin{tabular}{|lrccc|}
\hline \multirow{2}{*}{ Area } & \multirow{2}{*}{ (n) } & Prevalence & \multicolumn{2}{c|}{ Intensity (\%) } \\
& & $(\%)$ & Mean \pm SE & Range \\
\hline INS & $(109)$ & 22.0 & $1.64 \pm 0.47$ & $0.33-10.17$ \\
WC & $(50)$ & 54.0 & $1.61 \pm 0.30$ & $0.30-7.46$ \\
ONS & $(47)$ & 38.3 & $2.06 \pm 0.56$ & $0.27-10.13$ \\
Total & $(206)$ & 33.5 & $1.74 \pm 0.24$ & \\
& & & & \\
\hline
\end{tabular}


between periods ( $p=0.502)$, and the percent mature at this age in 2002 and 2003 was higher than in 1969 and 1970. Similarly, in west coast cod, mature fish at Age 3 and 4 yr were significantly smaller in 2002 and 2003 than in 1969 and 1970 ( $\mathrm{p}<0.01)$.

Within the overlapping fish length $(40$ to $80 \mathrm{~cm})$, there was a significant difference in the GW-length regression between the 2 periods in inshore North Sea and west coast cod (inshore North Sea: $\mathrm{n}=149, \mathrm{R}^{2}=$ 0.924; $p<0.001$ for length; $p<0.001$ for period; west coast: $\mathrm{n}=106, \mathrm{R}^{2}=0.964 ; \mathrm{p}<0.001$ for length; $\mathrm{p}<0.001$ for period). Inshore North Sea and west coast cod in 2002 and 2003 had 8 and $4 \%$ lower GW than in 1969 and 1970.

Temporal differences in length and age at maturity were significant in inshore North Sea cod (lengthmaturity: $\mathrm{n}=1288, \mathrm{R}^{2}=0.294 ; \mathrm{p}<0.001$ for length; $\mathrm{p}<$ 0.001 for period; age-maturity: $\mathrm{n}=741, \mathrm{R}^{2}=0.272$; $\mathrm{p}<$ 0.001 for age $; \mathrm{p}<0.001$ for period). Length and age at $50 \%$ maturity in inshore North Sea cod have declined by 36 and $6 \%$ respectively, since 1969 and 1970. In west coast cod there was no significant difference in length at maturity between the 2 periods ( $\mathrm{n}=519, \mathrm{R}^{2}=$ 0.233 ; $p<0.001$ for length; $p=0.111$ for period). Age did not significantly improve the model compared to the use of length alone.

There was a significant difference in the PF-length regression between the 2 periods in inshore North Sea cod within the size range 40 to $80 \mathrm{~cm}\left(\mathrm{n}=150, \mathrm{R}^{2}=\right.$ $0.723, p<0.001$ for length, $p<0.001$ for period). The PF in inshore North Sea cod in 2002 and 2003 was $21 \%$ higher than in 1969 and 1970. No significant difference in the $\mathrm{PF}$-length regression between periods was found in west coast cod in the same length range $(\mathrm{n}=$ $106, \mathrm{R}^{2}=0.748 ; \mathrm{p}<0.001$ for length; $\mathrm{p}=0.258$ for period).

In specimens from the inshore North Sea and west coast regions, mean calculated ovarian density for individuals ranging from 40 to $80 \mathrm{~cm}$ in length in 1969 and 1970 ( $\mathrm{n}=109,10938 \pm 585.8$ [PF ovarian weight $\left.\left.(\mathrm{OW})^{-1}\right]\right)$ was statistically similar to that in 2002 and 2003 ( $\mathrm{n}=146,9755 \pm 326.6$; $U$-test, $\mathrm{p}=0.480)$, indicating no effect on density between late maturing ovaries examined in the 2 periods. However there was a significant effect of period on the OW-length regression between the 2 periods $\left(n=255, R^{2}=0.561\right.$; $p<0.001$ for length; $\mathrm{p}<0.05$ for period; $\mathrm{p}=0.833$ for area).

The influence of relative condition factor $(K n)$ on the $\mathrm{PF}-$ length regression in inshore North Sea cod was significant, as was the effect of period $\left(\mathrm{n}=149, \mathrm{R}^{2}=\right.$ 0.782; $\mathrm{p}<0.001$ for length; $\mathrm{p}<0.001$ for $K n_{\text {; }} \mathrm{p}<0.001$ for period). A change in $K n$ from 0.8 to 1.2 resulted in an increase of $46 \%$ in PF in both periods (Fig. 5). In 2002 and 2003 the PF of cod for a given length was $32 \%$ higher than in 1969 and 1970 for same Kn. The

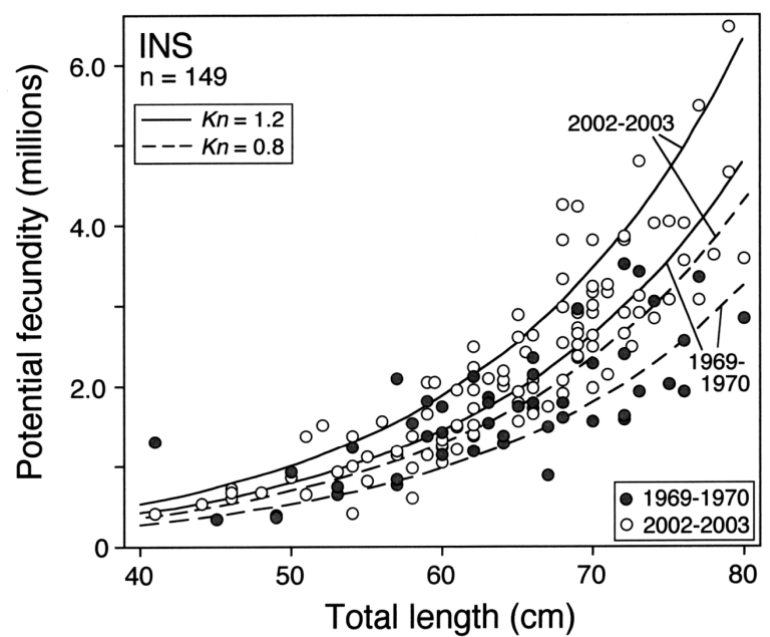

Fig. 5. Gadus morhua. Effect of relative condition factor $\mathrm{Kn}$ (Eq. 5) on total length-specific potential fecundity in inshore North Sea cod (INS) in 1969 and 1970 and 2002 and 2003. Regression line for generalized linear model fitted to potential fecundity at length regression line is shown for each period

influence of $K n$ on the PF-length regression in west coast cod was significant, but there was no significant difference in that model between the 2 periods $(\mathrm{n}=$ $106, \mathrm{R}^{2}=0.765 ; \mathrm{p}<0.001$ for length; $\mathrm{p}<0.01$ for $K n_{;} \mathrm{p}=$ 0.562 for period).

There was no significant difference in RF at Age $3 \mathrm{yr}$ between the 2 periods in inshore North Sea $\operatorname{cod}(\mathrm{n}=34$, $715 \pm 35.7$ for 2002, 2003; $U$-test, $\mathrm{p}=0.261$ ), whilst RF at Age $4 \mathrm{yr}$ in 2002 and 2003 was significantly higher than in 1969 and 1970 ( $\mathrm{n}=65,857 \pm 24.3$ for 2002, 2003; p < 0.001). In the west coast cod RF at Ages 3 and $4 \mathrm{yr}$ in 2002 and 2003 were statistically similar to those found in 1969 and 1970 (Age 3 yr: $\mathrm{n}=14,666 \pm 44.7$ for 2002, 2003; $\mathrm{p}=0.869 ;$ Age 4 yr: $\mathrm{n}=19,656 \pm 42.5$ for 2002, 2003; $\mathrm{p}=0.609$ ).

Overall, temporal variations in size and age at maturity in inshore North Sea cod were evident, with cod in 2002 and 2003 maturing at a smaller size and younger age than in 1969 and 1970. Differences in ovarian weights and the effect of body condition on fecundity between the periods showed that inshore North Sea cod are now more fecund than in 1969 and 1970.

\section{DISCUSSION}

This study demonstrated marked differences in the reproductive traits of inshore North Sea cod in 1969 and 1970 and in recent years. Cod in these waters now mature at a smaller size and younger age and their fecundity rate is much higher. There is a negative relation between the intercept and slope of the 
fecundity-length relationship. These trends are consistent with that associated with low adult fish survival reported in inter-species comparisons (e.g. Rochet 1998, Rochet et al. 2000). Changes in fecundity are not always associated with increased reproductive investment since there is a trade-off between the number of eggs and egg size (Bagenal 1973, Wootton 1990). Such a trade-off was found in North Sea plaice during a period of changing stock size, based on the relationship between ovarian weight and length (Rijnsdorp 1991). However, in the present study, ovarian density did not differ between study periods, but rather the recent increase in fecundity was associated with higher ovarian weight. Therefore, there appear to have been significant changes in the way in which cod allocate energy to reproduction in recent years.

A close relationship between growth and length and/or age at sexual maturity is usually seen in fishes (Rijnsdorp 1994, Trippel 1995), since the decision to invest in reproduction is related to surplus energy (Roff 1983). Given the decline in total stock biomass of North Sea cod since 1970 (ICES 2002a) any density-dependent limitation to growth would be expected to have declined (Trippel 1995, Jørgensen 1990). Cook et al. (1999) suggested that a trend towards younger maturity in North Sea cod between 1980 and 1995 was related to a density-dependent year-class effect on mean size at age. However, their analysis was based on combined data for both sexes and regions, ignoring known regional differences in size at age of cod in the North Sea (Rowell 1993) and sex-related differences in age at maturity (Brander 1994). Further, Rowell (1993) found only an effect of age on maturity when regional differences were excluded from analysis.

If the point of maturity were age- or size-dependent, then density-dependent growth would be expected to result in either larger size at maturity or earlier maturity. Maturation may also be related to growth rate rather than some size or age threshold, as Godø \& Haug (1999) found that rapidly growing cod can mature at shorter average lengths than slower-growing individuals. Our observations are not consistent with these predictions about changes in maturitylength relationships, since inshore North Sea cod now mature at a smaller size and this change is not associated with improved growth conditions prior to maturation. Shifts to a smaller size at maturity have been observed in the North Sea during the period between 1890 and 1990, when the stock biomass was much higher than in recent times (Oosthuizen \& Daan 1974, Rowell 1993). Rowell (1993) also reported that this did not correspond to any notable change in growth rate. Rijnsdorp et al. (1991) did not find a trend in variation of age at maturity in North Sea cod in the 1980s, when the SSB gradually decreased. Oosthuizen \& Daan
(1974) suggested that the shift to smaller size at maturity in North Sea cod seen by the 1970s was due to size selection brought about by the fishery, since there was no clear environmental covariate. Rowell (1993) concluded that these changes in North Sea cod might be the result of genetic selection for early maturing genotypes. Although no information on the environmental or energy allocation history of the cod was considered in the present study, the change in the maturity-size relationship in inshore North Sea cod could partly be attributable to a genetic selection towards smaller size at maturity.

The temporal variations calculated for size and age at maturity in west coast cod may not be completely accurate, since fish size and age ranges available in the study of West (1970) were rather limited. Statistically there was no clear evidence for significant changes in these traits between the periods considered. However, our findings imply that the present stocks of cod off the west coast of Scotland may mature at a smaller size and younger age than in 1969 and 1970. Length at $50 \%$ maturity was $45 \mathrm{~cm}$ in 1969 and 1970 whilst in 2002 and 2003 it was $40 \mathrm{~cm}$. Lengths of mature females at Ages 3 and 4 yr are now significantly smaller than in 1969 and 1970.

Insufficient nutrient stores before spawning can lead to an increased incidence of egg atresia in cod, and even to spawning failure in the severest cases (Kjesbu et al. 1991, Marshall et al. 1998, Rideout et al. 2000). However, atresia levels had little effect on potential fecundity in the stages of vitellogenesis we examined. Therefore the spatial variation in fecundity observed is unlikely to have been due to different levels of oocyte resorption during late vitellogenesis.

Significant spatial variations in potential and relative fecundities of cod in Scottish waters were found in 2002 and 2003. The cause of this variation may be partly food-related as a positive relationship between food availability and fecundity occurs in wild and captive fishes (Bagenal 1973, Wootton 1990). In captive Atlantic cod, in situations of decreasing available energy reserves, females tend to reduce reproductive investment by decreasing fecundity (Lambert \& Dutil 2000). Our findings indicated that the condition of the liver significantly influenced fecundity in inshore North Sea and Scottish west coast cod. This has also been found in Arctic and Icelandic cod (Kjesbu et al. 1998, Marteinsdottir \& Begg 2002). The liver is the main storage for lipids in cod (Lambert \& Dutil 1997) and thus affects fecundity. However, the spatial variation in fecundity in recent years cannot be solely explained in terms of nutrition, since similar gutted body and liver weights for a given size were found in all 3 areas. Thus inshore North Sea cod could allocate more energy to reproduction than any other area 
examined. Atlantic silverside Menida menida also exhibit spatial variation in energy allocation to growth and reproduction (Billerbeck et al. 2000), with spatial variation arising through latitudinal differences in overwinter mortality between genetically distinct populations (Schultz \& Conover 1997).

As in Rijnsdorp et al.'s (1991) study of southern North Sea cod, the increase in relative fecundity found in the present study was associated with a decrease in SSB. Rijnsdorp et al. (1991) proposed the change to be due to a density-dependent response. However, they did not investigate whether there were any changes in energy allocation to reproduction during that period. The temporal variation in the effect of body condition on fecundity observed in inshore North Sea cod suggests a change in energy allocation to reproductive output. The relative fecundity in cod in recent years is positively correlated with age, suggesting that there may be a significant difference in reproductive output between first and repeat spawners and even among repeat spawners. In contrast, the lack of such a relationship in the 1970s implies that annual reproductive investment was then independent of spawning experience. The combination of an increasing investment of energy in fecundity and a smaller size and younger age at maturity in inshore North Sea cod in recent years appears consistent with pheno- and genotypic selection predicted by life-history theory (Rochet 1998, Rochet et al. 2000).

In conclusion, our study indicates that reproductive investment in cod in Scottish waters has changed since the period of high population biomass of inshore North Sea cod (1969 and 1970), and these now mature at a younger age, and have the potential to produce many more eggs by their maximum age without any improvement in growth conditions. This study does not identify the mechanisms for this change. However, these observations are consistent with genotypic changes in life-history traits predicted to arise from intense periods of size-selective mortality (Law 2000, Rochet et al. 2000). This study also found that in recent years, maturity and fecundity in pre-spawning females has differed among areas. The spatial variation in those parameters may reflect population differences. Hutchinson et al. (2001) found evidence of at least 2 genetically distinct populations within our North Sea study area. Mortality may also have differed between the east and west areas of the North Sea investigated in the present study, since fishing effort in eastern waters, particularly in the coastal waters off Scotland, has historically been at its highest levels during the last 40 yr (Greenstreet et al. 1999). The variations in reproductive parameters reported here also indicate that the stock reproductive potential for a given SSB has changed and this should be taken into account in the development of more realistic recruitment-stock relationships (Marshall et al. 1998, Scott et al. 1999).

Acknowledgements. We are grateful to I. Gibb, F. Gibb and G. Strugnell for helping with collection and measurement of specimens, to F. Neat for constructive criticisms of the manuscript and to 4 anonymous referees for their valuable comments and suggestions. We acknowledge a grant to M.Y. from the Japan Society for the Promotion of Science for Research Abroad in 2002. This work was conducted as part of a contract with the European Union METACOD Q5RS-2001-00953 and the Scottish Executive MF0462.

\section{LITERATURE CITED}

Bagenal TB (1973) Fish fecundity and its relations with stock and recruitment. Rapp P-V Réun Cons Int Explor Mer 164: 186-198

Billerbeck JM, Schultz ET, Conover DO (2000) Adaptive variation in energy acquisition and allocation among latitudinal populations of the Atlantic silverside. Oecologia 122: 210-219

Brander KM (1994) Spawning and life history information for North Atlantic cod stocks. Int Counc Explor Sea Coop Res Rep 205. ICES, Copenhagen

Cook RM, Sinclair A, Stefánsson G (1997) Potential collapse of North Sea cod stocks. Nature 385:521-522

Cook RM, Kunzlik PA, Hislop JRG, Poulding D (1999) Models of growth and maturity for North Sea cod. J Northwest Atl Fish Sci 25:91-99

Cushing DH (1984) The gadoid outburst in the North Sea. J Cons Int Explor Mer 41:159-166

Godø OR, Haug T (1999) Growth rate and sexual maturity in cod (Gadus morhua) and Atlantic halibut (Hippoglossus hippoglossus). J Northwest Atl Fish Sci 25:115-123

Graham MBA (1923) The annual cycle in the life of the mature cod in the North Sea. Fish Investig Ser II Mar Fish GB Minist Agric Fish Food 6. His Majesty's Stationery Office, London

Greenstreet SPR, Spence FB, Shanks AM, McMillan JA (1999) Fishing effects in northeast Atlantic shelf seas: patterns in fishing effort, diversity and community structure. II. Trends in fishing effort in the North Sea by UK registered vessels landing in Scotland. Fish Res 40: $107-124$

Hislop JRG (1996) Changes in North Sea gadoid stocks. ICES J Mar Sci 53:1146-1156

Hunter JR (1985) Preservation of northern anchovy in formaldehyde solution. NOAA Tech Rep NMFS 36:63-65

Hunter JR, Macewicz BJ (1985) Measurement of spawning frequency in multiple spawning fishes. NOAA Tech Rep NMFS 36:79-94

Hutchings JA (2000) Collapse and recovery of marine fishes. Nature 406:882-885

Hutchinson WF, Carvalho GR, Rogers SI (2001) Marked genetic structuring in localised spawning populations of cod Gadus morhua in the North Sea and adjoining waters, as revealed by microsatellites. Mar Ecol Prog Ser 223: $251-260$

ICES (International Council for the Exploration of the Sea) (1999) Manual for the international bottom trawl surveys, Revision VI. Int Counc Explor Sea Comm Meet D:2. ICES, Copenhagen

ICES (International Council for the Exploration of the Sea) (2002a) Report of the ICES advisory committee on the 
marine environment 2002. Int Counc Explor Sea Coop Res Rep 255. ICES, Copenhagen, p 215-345

ICES (International Council for the Exploration of the Sea) (2002b) Report of the working group on the assessment of demersal stocks in the North Sea and Skagerrak. Int Counc Explor Sea Comm Meet ACFM:02. ICES, Copenhagen

Jørgensen T (1990) Long-term changes in age at sexual maturity of Northeast Arctic cod (Gadus morhua L.). J Cons Int Explor Mer 46:235-248

Kjesbu OS, Lungsøyr J, Kryvi H, Witthames PR, Greer Walker M (1991) Fecundity, atresia, and egg size of captive Atlantic cod (Gadus morhua) in relation to proximate body composition. Can J Fish Aquat Sci 48:2333-2343

Kjesbu OS, Witthames PR, Solemdal P, Greer Walker M (1998) Temporal variations in the fecundity of ArctoNorwegian cod (Gadus morhua) in response to natural changes in food and temperature. J Sea Res 40:303-321

Lambert Y, Dutil JD (1997) Can simple condition indices be used to monitor and quantify seasonal changes in the energy reserves of Atlantic cod (Gadus morhua)? Can J Fish Aquat Sci 54(Suppl 1):104-112

Lambert Y, Dutil JD (2000) Energetic consequences of reproduction in Atlantic cod (Gadus morhua) in relation to spawning level of somatic energy reserves. Can J Fish Aquat Sci 57:815-825

Law R (1979) Optimal life history under age-specific predation. Am Nat 114:399-417

Law R (2000) Fishing, selection, and phenotypic evolution. ICES J Mar Sci 57:659-668

Le Cren ED (1951) The length-weight relationship and seasonal cycle in gonad weight and condition in the perch Perca fluviatilis. J Anim Ecol 20:201-219

Marshall CT, Kjesbu OS, Yaragina NA, Solemdal P, Ulltang Ø (1998) Is spawner biomass a sensitive measure of the reproductive and recruitment potential of Northeast Arctic cod? Can J Fish Aquat Sci 55:1766-1783

Marteinsdottir G, Begg GA (2002) Essential relationships incorporating the influence of age, size and condition on variables required for estimation of reproductive potential in Atlantic cod Gadus morhua. Mar Ecol Prog Ser 235: 235-256

MathSoft (2000) S-PLUS: guide to statistics. Data Analysis Products Division, MathSoft, Seattle, WA

Michod RE (1979) Evolution of life histories in response to age-specific mortality factors. Am Nat 113:531-550

Myers RA, Hutchings JA, Barrowman NJ (1996) Hypotheses for the decline of cod in the North Atlantic. Mar Ecol Prog Ser 138:293-308

Oosthuizen E, Daan N (1974) Egg fecundity and maturity of North Sea cod, Gadus morhua. Neth J Sea Res 8:378-397

Óskarsson GJ, Kjesbu OS, Slotte A (2002) Predictions of realised fecundity and spawning time in Norwegian spring-spawning herring (Clupea harengus). J Sea Res 48: 59-79

Poulsen EM (1931) Biological investigation upon the cod in Danish waters. Medd Kom Dan Fisk Havunders Fisk 2: $1-148$

Reznick DA, Bryga H, Endler JA (1990) Experimentally induced life-history evolution in a natural population. Nature 346:357-359

Rideout RM, Burton MPM, Rose GA (2000) Observations on mass atresia and skipped spawning in northern Atlantic cod, from Smith Sound, Newfoundland. J Fish Biol 57: $1429-1440$

Rijnsdorp AD (1991) Changes in fecundity of female North Sea plaice (Pleuronectes platessa L.) between three periods since 1900. ICES J Mar Sci 48:253-280

Rijnsdorp AD (1994) Population-regulating processes during the adult phase in flatfish. Neth J Sea Res 32:207-223

Rijnsdorp AD, Daan N, van Beek FA, Hessen HJL (1991) Reproductive variability in North Sea plaice, sole and cod. J Cons Int Explor Mer 47:352-375

Rochet M (1998) Short-term effects of fishing on life history traits of fishes. ICES J Mar Sci 55:371-391

Rochet M, Cornillon P, Sabatier R, Pontier D (2000) Comparative analysis of phylogenetic and fishing effects in life history patterns of teleost fishes. Oikos 91:255-270

Roff DA (1983) An allocation model of growth and reproduction in fish. Can J Fish Aquat Sci 40:1395-1403

Rowell CA (1993) The effects of fishing on the timing of maturity in North Sea cod (Gadus morhua L.). Lect Notes Biomath 99:44-61

Schultz ET, Conover DO (1997) Latitudinal differences in somatic energy storage: adaptive responses to seasonality in an estuarine fish (Atherinidae: Menidia menidia). Oecologia 109:516-529

Scott B, Marteinsdottir G, Wright P (1999) Potential effects of maternal factors on spawning stock-recruitment relationships under varying fishing pressure. Can J Fish Aquat Sci 56:1882-1890

Shopka VSA (1971) Vergleichende Untersuchungen zur Fortpflanzungsrate bei Herings- und Kabeljaupopulationen (Clupea barengus L. und Gadus morhua L.). Ber Dtsch Wiss Komm Meeresforsch 22:31-79

Stearns SC (1992) The evolution of life histories. Oxford University Press, Oxford

Swartzman G, Silverman E, Williamson N (1995) Relating trends in walleye pollock (Theragra chalcogramma) abundance in the Bering Sea to environmental factors. Can J Fish Aquat Sci 52:369-380

Thorsen A, Kjesbu OS (2001) A rapid method for estimation of oocyte size and potential fecundity in Atlantic cod using a computer-aided particle analysis system. J Sea Res 46: 295-308

Trippel EA (1995) Age at maturity as a stress indicator in fisheries. BioScience 45:759-771

Trippel EA, Mork J (2004) Correlation analysis of fisheriesinduced adaptive change. In: Dieckmann U, Godø OR, Heino M, Mork J (eds) Fisheries-induced adaptive change. Cambridge University Press, Cambridge (in press)

Trippel EA, Kjesbu OS, Solemdal P (1997) Effects of adult age and size structure on reproductive output in marine fishes. Fish Fish Ser 21:31-62

West WQB (1970) The spawning biology and fecundity of cod in Scottish waters. PhD thesis, University of Aberdeen, Aberdeen

Witthames PR, Greer Walker M (1995) Determinacy of fecundity and oocyte atresia in sole (Solea solea) from the Channel, the North Sea and the Irish Sea. Aquat Living Resour 8:91-109

Wootton RJ (1990) Ecology of teleost fishes. Chapman \& Hall, London

Submitted: September 3, 2003; Accepted: March 25, 2004

Proofs received from author(s): July 5, 2004 